\title{
Multiple endocrine neoplasia
}

INSERM

\section{Source}

INSERM. (1999). Orphanet: an online rare disease and orphan drug data base. Multiple endocrine neoplasia. ORPHA:276161

Multiple endocrine neoplasia (MEN) is a group of rare inherited cancer syndromes characterized by the development of two or more endocrine gland tumors, sometimes with tumor development in other tissues or organs. 